\title{
Solar Panel Measurement System using Arduino with Bluetooth
}

\author{
Al Qindi M. Yusuf, Evanco Hollis N.P. Simangunsong, Indah Tria Wilyani, Iksan Bukhori \\ Study Program of Electrical Engineering, President University, Bekasi 17550, Indonesia \\ Corresponding author: iksan.bukhori@ president.ac.id
}

\begin{abstract}
This project aims to develop a measurement of solar energy using Arduino. In this research, two parameters that been measured are light intensity and the voltage. The light intensity was measured using light dependent resistor (LDR) sensor. The voltage was measured using the voltage divider because the voltage generated by the solar panel are large for the Arduino as receiver. These parameters as the input value for the Arduino and the output was display at the Arduino Bluetooth Controller. The Arduino Bluetooth controller display output of the light intensity and the voltage value. The purpose of using Arduino is to convert the analog input of parameter to the digital output and display via Bluetooth.
\end{abstract}

Keywords: Light, measurement, voltage

\section{INTRODUCTION}

Rising fossil gas and burning gas such as coal, international warming and intense weather situations have compelled many countries to search for alternative assets to lessen reliance on fossil based totally fuels. Solar energy is one of the most promising renewable sources that is currently being used worldwide to contribute for meeting rising demands of electric power [1]. Solar power is a conversion of sunlight into electricity, sunlight was collected either directly by using photovoltaics or indirectly using concentrated of solar energy [2]. Photovoltaics was to begin with use as a power supply for a small and medium size program from the calculator powered by means of an unmarried solar mobile to a remote home powered by way of an off-grid rooftop photovoltaics system. In this project, a simple solar panel measurement system using arduino uno with Bluetooth is introduced.

\section{LITERATURE REVIEW}

\section{A. Solar Cell}

The solar panel is a device composed of semiconductor materials can convert sunlight into electricity directly. Often too the term photovoltaic is used.

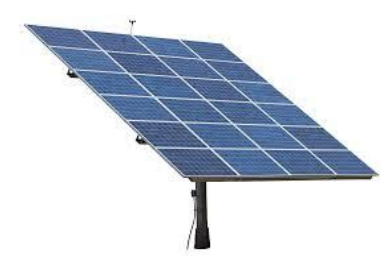

Figure 1. Solar cell
When sunlight hits the surface of the solar cell, the energy carried by this sunlight will absorbed by electrons in the p-n junction to move from the diode $\mathrm{p}$ to $\mathrm{n}$ and henceforth flows out through the cable attached to the panel.

\section{B. Arduino Uno}

The Arduino Uno is microcontroller board based on the ATmega328 as shown in Figure 2. It has 14 digital input and output pins: 6 pins used PWM outputs and 6 pins is analog input such as the clock speed is $16 \mathrm{MHz}$, the ceramic resonator, the USB connection, the power jack, the ICSP header and the reset button [3].

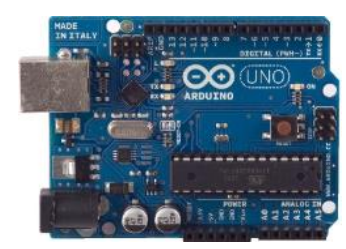

Figure 2. Arduiono Uno

Specification for Arduino as used in this project is shown in Table 1.

Table 1. Arduino specification

\begin{tabular}{|c|c|}
\hline MICROCONTROLER & Atmega28 \\
\hline Operating voltage & $5 \mathrm{~V}$ \\
\hline Input voltage & $7-12 \mathrm{~V}$ \\
\hline Digital I/O Pins & 14 \\
\hline Analog input pins & 6 \\
\hline DC current per I/O & $40 \mathrm{~mA}$ \\
\hline DC current for 3 - 3v pin & $50 \mathrm{~mA}$ \\
\hline
\end{tabular}




\begin{tabular}{|c|c|}
\hline Flash memory & $32 \mathrm{kB}$ \\
\hline Clock speed & $16 \mathrm{MHz}$ \\
\hline
\end{tabular}

\section{HC-05 Bluetooth Module}

The HC-05 is a very cool module which can add twoway (full-duplex) wireless functionality to projects. One can use this module to communicate between two microcontrollers like Arduino or communicate with any device with Bluetooth functionality like a phone or laptop. This device is shown in Figure 3.
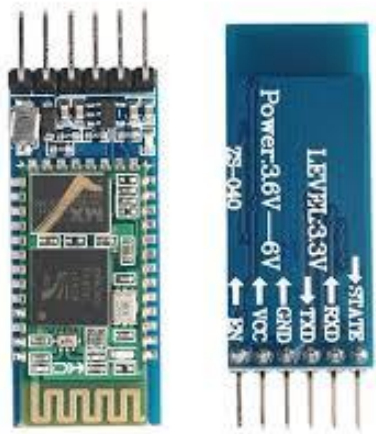

Figure 3. HC-05 Bluetooth module

There are several pins on HC-05 modules. Each of this pin functionallity can be seen in Table 2 .

Table 2. HC-05 pinout

\begin{tabular}{|c|c|c|}
\hline $\begin{array}{c}\text { Pin } \\
\text { Number }\end{array}$ & Pin Name & Description \\
\hline 1 & $\begin{array}{c}\text { Enable / } \\
\text { Key }\end{array}$ & $\begin{array}{l}\text { This pin is used to toggle between Data } \\
\text { Mode (set low) and AT command mode } \\
\text { (set high). By default, it is in Data mode }\end{array}$ \\
\hline 2 & Vec & $\begin{array}{l}\text { Powers the module. Connect to }+5 \mathrm{~V} \\
\text { Supply voltage }\end{array}$ \\
\hline 3 & Ground & $\begin{array}{l}\text { Ground pin of module, connect to system } \\
\text { ground. }\end{array}$ \\
\hline 4 & $\begin{array}{c}\mathrm{TX}- \\
\text { Transmitter }\end{array}$ & $\begin{array}{l}\text { Transmits Serial Data. Everything } \\
\text { received via Bluetooth will be given out } \\
\text { by this pin as serial data. }\end{array}$ \\
\hline 5 & $\begin{array}{c}\mathrm{RX}- \\
\text { Receiver }\end{array}$ & $\begin{array}{c}\text { Receive Serial Data. Every serial data } \\
\text { given to this pin will be broadcasted via } \\
\text { Bluetooth }\end{array}$ \\
\hline 6 & State & $\begin{array}{l}\text { The state pin is connected to on board } \\
\text { LED, it can be used as a feedback to } \\
\text { check if Bluetooth is working properly. }\end{array}$ \\
\hline 7 & LED & $\begin{array}{l}\text { Indicates the status of Module } \\
\text { Blink once in } 2 \text { sec: Module has } \\
\text { entered Command Mode } \\
\text { - } \quad \text { Repeated Blinking: Waiting for } \\
\text { connection in Data Mode } \\
\text { Blink twice in 1 sec: Connection } \\
\text { successful in Data Mode }\end{array}$ \\
\hline 8 & Button & $\begin{array}{l}\text { Used to control the Key/Enable pin to } \\
\text { toggle between Data and command Mode }\end{array}$ \\
\hline
\end{tabular}

Connection between Arduino and HC-05 used in this project is shown in Figure 4.

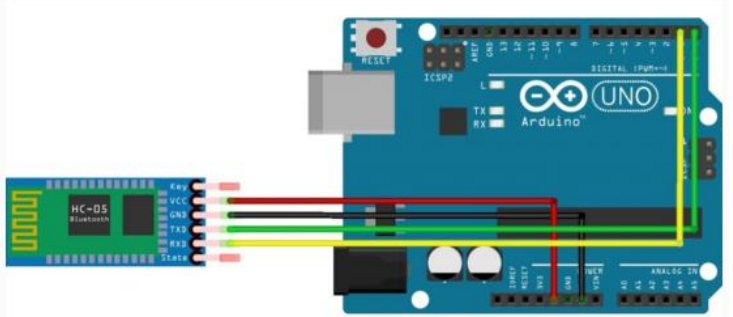

Figure 4. Arduino Uno to HC-05 Bluetooth module

\section{Light Sensor}

A Light Dependent Resistor (LDR) or photo resistor is device whose resistivity is a function of the incident electromagnetic radiation which means it is light sensitive devices. These components also called a photoconductor, photo conductive cells or simply photocells [4]. The appearance of this device can be seen in Figure 5

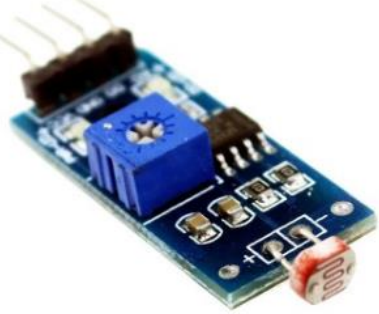

Figure 5. LDR sensor

The LDR function on the principle based on photo conductivity which an optical phenomenon. Figure 6 shows the resistance vs illumination graph of LDR.

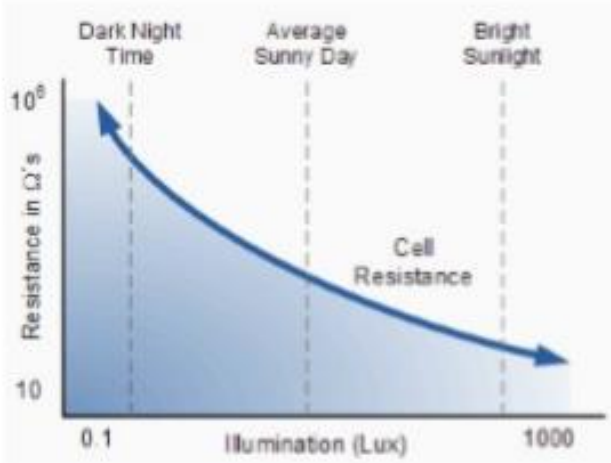

Figure 6. The resistance vs illumination graph of LDR

\section{DESIGN IMPLEMENTATION}

Figure 7 shows the prototype of solar energy measurement using Arduino Uno. 


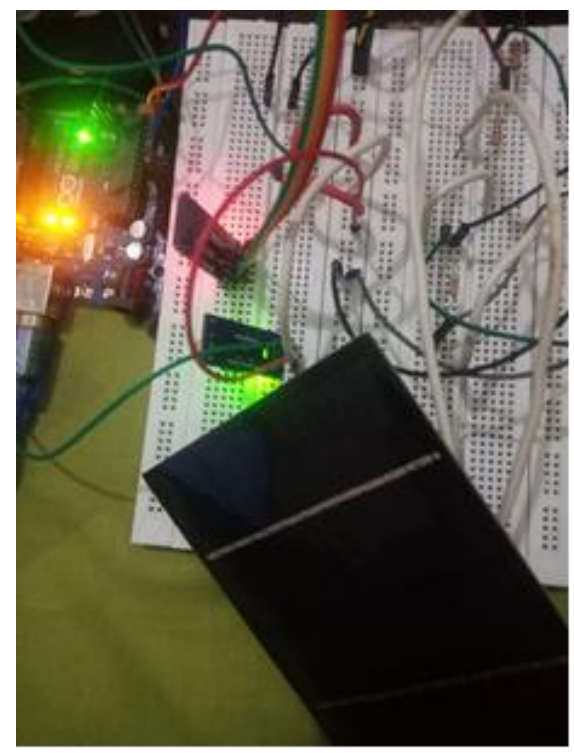

Figure 7. The prototype

\section{RESULT AND ANALYSIS}

This section discusses the results based on the simulation results and the measurement result.

\section{A. Simulation Result}

Figure 8 shows the results of the reading voltage and light intensity. It varies depend on the sunlight during the simulation.

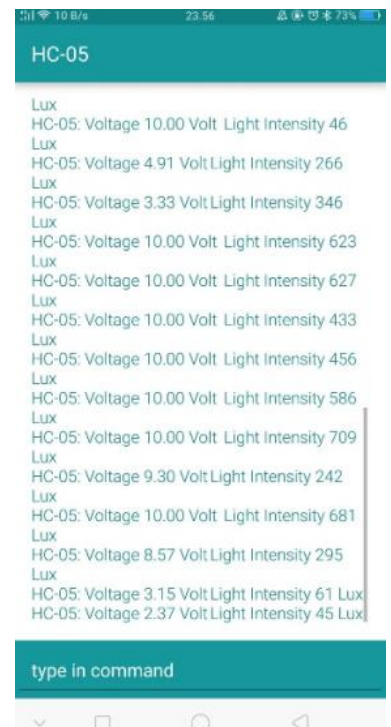

Figure 8. The reading of HC-05 Bluetooth module

Table 3 shows the simulation result of light intensity and the output voltage. From the simulation results shown that the circuit are function is very well and can be continue to the hardware development.
Table 3. LDR simulation result

\begin{tabular}{|c|c|}
\hline Output Voltage (V) & LDR Intensity \\
\hline 4.91 & 266 \\
\hline 8.57 & 242 \\
\hline 9.30 & 295 \\
\hline 10.00 & 456 \\
\hline 10.00 & 586 \\
\hline 10.00 & 709 \\
\hline
\end{tabular}

\section{B. Measurement Result}

The light intensity had been recorded in the two days with the solar panel, the sunrise role as proven in Figure 9. Based on the result, the highest light intensity changed into 980 Lux at 2.00 p.m., at the same time as the lowest mild intensity become 700 Lux at 5.00 p.m.

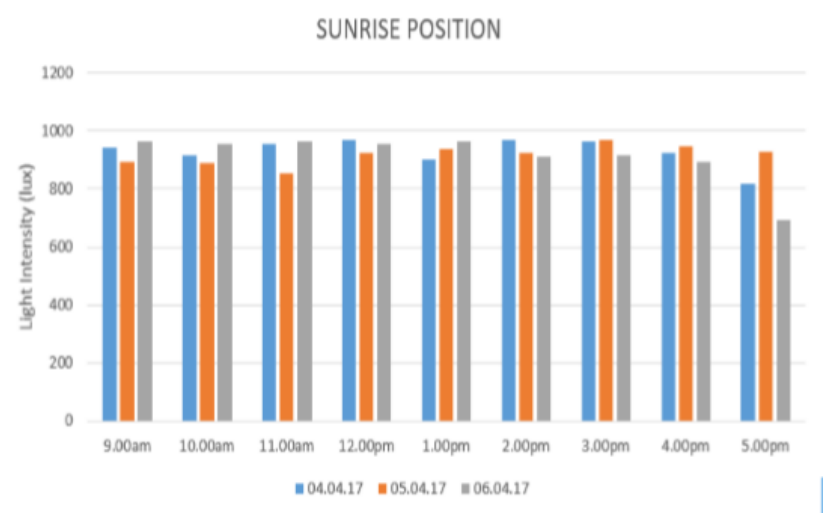

Figure 9. Result of light intensity for sunrise position

The light intensity had been recorded in two days with the solar panel inside the sunrise role as the proven in Figure 9. Based on result, the highest upward intensity turned into 970 Lux at 11.00 a.m., whilst the lowest upward became 350 Lux at 5.00 p.m.

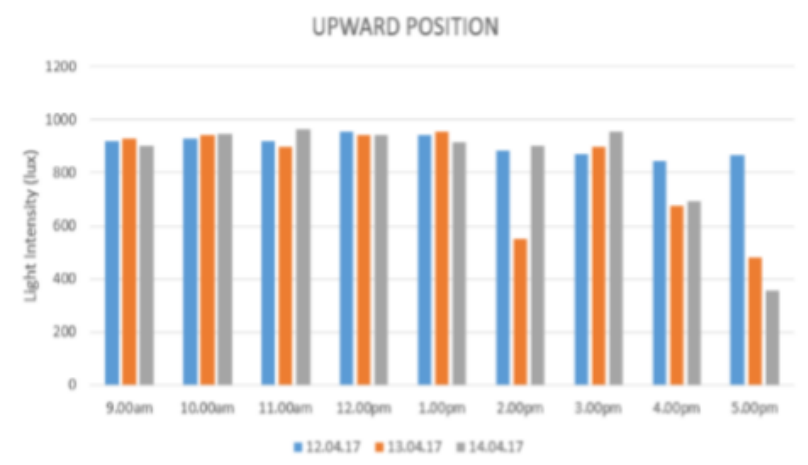

Figure 10. Result of light intensity for upward position

Table 4 shown the maximum and the minimum of the light intensity that have been recorded according to their solar panel position. 
Table 4. Maximum and minimum light intensity

\begin{tabular}{|c|c|c|}
\hline Position & Sunrise & Upward \\
\hline Maximum & 900 Lux at & 970 Lux at \\
(Lux) & 2.00 p.m. & 11.00 a.m. \\
\hline Minimum & 700 Lux at & 350 Lux at \\
(Lux) & 5.00 p.m. & 5.00 p.m. \\
\hline
\end{tabular}

\section{Conclusion}

In the conclusion, the implementation of solar panel measurement using Bluetooth that can be used to monitor the voltage of solar panel, also to track the intensity of the light in the area. Moreover the system also can send the measurement data to mobile phone through Bluetooth communication. For the light intensity parameter was by using the LDR sensor, for the voltage parameter was by using the voltage divider method in order to reduce the maximum value of the solar panel to the voltage value suitable for the Arduino of power supply and lastly the current parameter was by using the current sensor module.
For future work reset, reseacher have some suggestion based on the research, in terms of communication Bluetooth can be changed to ESP 8266 module. so the range will be longer and create a more steady communication to the smartphone and add some sensors to improve the system.

\section{REFERENCE}

[1] John Balfaour, Introduction to Photovoltaic, United States of America, 2013.

[2] V. Ryan, what is solar energy, 2016. [Online]. Available: https://www.technologicalstudent.com. [Accessed September 20, 2016].

[3] Chua Chua Hock-Chuan, Getting Started with Arduino, 2016. [Online]. Available:

https://www.ntu.edu.sg/home/enchua/programing/arduino/arduino.ht ml. [Accessed September 20, 2016].

[4] R. Electrical 4U, Light Dependent Resistor / LDR and working Principle of LDR, 2016. [Online]. Available: http://www.electrical4u.com/light-depend. [Accessed November 2, 2016]. 